\title{
Epi-Brassinolide Positively Affects Chlorophyll Content and Dark-Reaction Enzymes of Maize Seedlings
}

\author{
Yuanfen Gao, Tinglan Jiang, Yin Xiang, Xuewu He, Zhen Zhang, Shengjuan Wen and Junjie Zhang* \\ College of Life Sciences, Sichuan Agricultural University, Yảan, 625014, China \\ ${ }^{*}$ Corresponding Author: Junjie Zhang. Email: junjiezhang@sicau.edu.cn \\ Received: 13 October 2020 Accepted: 15 March 2021
}

\begin{abstract}
Brassinosteroids participate in many physiological processes in plants; however, their regulatory roles on the activities of the enzymes involved in dark phase of photosynthesis remains elusive. In this study, detached leaves and protoplasts of maize seedlings were treated with epi-brassinolide (EBR) and brassinazole followed by the determination of the contents of chlorophyll $(\mathrm{a}+\mathrm{b})$ and soluble sugars, and the activity of dark reaction enzymes and the expression of the relevant genes. The results showed that chlorophyll $(\mathrm{a}+\mathrm{b})$ content increased by $7.4 \%$ under $0.1 \mu \mathrm{M}$ EBR treatment for $48 \mathrm{~h}$; furthermore, chlorophyll $(\mathrm{a}+\mathrm{b})$ content increased by $34 \%$ in detached leaves that were continuously soaked in brassinazole. In addition, the transcription levels of glyceraldehyde3-phosphate dehydrogenase subunit A (GAPA), cytoplasmic FBPase (cyFBPase), ribulose-1,5-bisphosphate carboxylase small subunit ( $r b c S)$, phosphoenolpyruvate carboxylase (PEPC), fructose-1,6-bisphosphatase (FBPase), Rubisco activase $\beta$ subunit $(R C A \beta)$, ribulose-l,5-bisphosphate carboxylase large subunit (rbcL), and glutathione reductase (GR) were $96.8 \%, 48.4 \%, 79.3 \%, 41 \%, 85.6 \%, 133.3 \%, 68.8 \%$, and $119.8 \%$ higher, respectively, in $0.1 \mu \mathrm{M}$ EBR than in the control group. The activity of RCA and Rubisco and soluble sugar content increased by $53.4 \%, 28.7 \%$, and $35.4 \%$ under $0.1 \mu \mathrm{M}$ EBR. Brassinazole inhibits the expression of these genes. However, the transcription level, protein content, and activity of some dark-reaction enzymes cannot be increased at the same time under EBR treatment. These results indicate that the effect of EBR on dark-reaction is mainly in transcription level.
\end{abstract}

\section{KEYWORDS}

Zea mays; epi-brassinolide; brassinazole; rbcL; RCA; PEPC; soluble sugar

\section{Introduction}

Photosynthesis is an important process for generating energy and providing organic materials to plants. Photosynthesis depends on light intensity, light energy conversion, and carbon assimilation [1]. The strategy for light absorption and energy conversion is to expand the absorption spectrum or the continuous development of photosynthetic devices to improve light absorption [2]. The carbon-fixation reaction-an essential part of photosynthesis and a common physiological process in green plants - provides a basic skeleton for cell building blocks [3]. In addition to the improvement of photosynthetic light capture efficiency, increasing the carbon-fixation enzyme expression is considered a possible strategy for increasing crop yields [4].

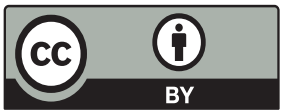

This work is licensed under a Creative Commons Attribution 4.0 International License, which permits unrestricted use, distribution, and reproduction in any medium, provided the original work is properly cited. 
Brassinosteroids (BRs), a type of sterols, are essential hormones in plants. More than 70 BRs have been found, and these are widely present in the pollen, fruit, seeds, leaves, roots, and stems of plants [5]. BRs are known to have high physiological activity as plant growth regulation. The roles of BRs in regulation of photosynthesis mechanisms for improving crop yield and quality has become an important area of agricultural research [6]. Arabidopsis thaliana mutant defective in BRs biosynthesis mutant showed dwarfism and delayed-growth phenotype with dark green leaves, which were restored after the addition of exogenous BRs [7]. BRs are pleiotropic and can regulate the growth and development of plants, affect the synthesis of other hormones and certain secondary metabolites, and also regulate photosynthesis under normal or abnormal conditions to improve the efficiency of photosynthetic carbon fixation [8]. The BRs play a role in crop yield by affecting the dark reaction. Lack of BRs synthesis leads to metabolic disorders and biomass reduction in Arabidopsis, whereas increased levels of endogenous BRs can escalate $\mathrm{CO}_{2}$ assimilation capacity and sugar content, promote the transport of assimilates to the grain, and increase yield in rice (Oryza sativa) [9]. Treatment with BRs affects the photosynthetic capacity of soybean (Glycine max) [10] and mustard (Brassica juncea) [11], leading to heightened biomass and seed yield. The effect of BRs on photosynthesis is mainly because of the increase in photosynthetic pigment content, net photosynthetic rate, calvin cycle enzyme activity, and the expression of carbon fixation-related genes, which are found in many plants, such as barley (Hordeum vulgare) [12], cucumber (Cucumis sativus) [13], tomato (Solanum lycopersicum) [14], and nursery apple (Malus domestica) trees [15].

Maize (Zea mays) is one of the world's major crops, and considerable attention has been paid to increasing its productivity. Some studies have focused on enhancing maize photosynthesis to increase yield [16]. Maize BR synthetic mutant brdl (BR-deficient $d$ warfl) results in a strong dwarf phenotype and aberrant leaf structure without yellowing [17]. Also, it has been found that the application of epibrassinolide (EBR) increases the chlorophyll $b$ content and net photosynthetic rate of young maize leaves after 7 days [18]. However, the effect of EBR on the dark reaction of maize seedlings is unclear, and this is important for understanding the potential efficacy of applying EBR to improve yield. Our goal was to explore the effect of different concentrations of EBR treatment on the photosynthesis of maize seedlings and to determine the chlorophyll and soluble sugar contents, the carbon-fixation reaction enzyme activity, and expression of relevant genes in maize leaves after EBR and brassinazole (BRZ) treatment.

\section{Materials and Methods}

\subsection{Plant Materials and Growth Conditions}

Maize inbred line Mo17 was provided by Sichuan Agricultural University, China. Maize seeds were sown in soil, with a ratio of vermiculite to peat soil $1: 1(\mathrm{v} / \mathrm{v})$, and cultivated in a smart light incubator (MGC-250H, Shengyuan Instrument, China), with a light/dark cycle of $16 \mathrm{~h} / 8 \mathrm{~h}$ and light intensity of $3,000 \mathrm{~lx}$. The day/night temperature was $25^{\circ} \mathrm{C} / 23^{\circ} \mathrm{C}$. Maize seedlings with two leaves and one cob were selected for the experiment.

\subsection{EBR and BRZ Treatment of Seedlings and Protoplasts}

The leaves were cut into $1 \mathrm{~cm}$ long leaf segments, and after mixing, divided into three groups, each with six samples, with each sample containing $2 \mathrm{~g}$ (fresh weight) of leaf material. Different samples were cultured in medium supplemented with $1 \mathrm{~mL}$ distilled water, $4 \mu \mathrm{M}$ BRZ (Solarbio, Beijing, China) or different concentrations of EBR (Solarbio). The EBR concentration was set to 0.02, 0.05, 0.1, 0.2, 0.5, and $1.0 \mu \mathrm{M}$, and the different groups were placed in an incubator for $6 \mathrm{~h}, 12 \mathrm{~h}$, and $24 \mathrm{~h}$. The second leaf of the two-leaf one-cob maize seedling was digested using cellulase and macerozyme to obtain protoplasts [19]. The separated protoplasts were resuspended in a solution containing $95 \% \mathrm{~W} 5(154 \mathrm{mmoL} / \mathrm{L}$ $\mathrm{NaCl}, 125 \mathrm{mmol} / \mathrm{L} \mathrm{CaCl}, 2 \mathrm{mmol} / \mathrm{L} \mathrm{MES})$ and 5\% WI $(4 \mathrm{mmoL} / \mathrm{L} \mathrm{MES}, 0.4 \mathrm{moL} / \mathrm{L}$ mannitol, 
$5 \mathrm{mmol} / \mathrm{L} \mathrm{KCl}$ ). The same quantity of protoplasts and EBR were deposited into $2 \mathrm{~mL}$ Eppendorf tubes, mixed gently, and cultured at $25^{\circ} \mathrm{C}$ under $2,000 \mathrm{~lx}$ for $12 \mathrm{~h}$.

\subsection{Chlorophyll Content}

Leaves from similar positions were selected and cut into thin strips $\left(2.3079 \mathrm{~cm}^{2}\right)$ that were soaked in $10 \mathrm{~mL}$ of a mixture containing acetone and ethanol at a ratio of $2: 1(\mathrm{v} / \mathrm{v})$ at $25^{\circ} \mathrm{C}$ for $24 \mathrm{~h}$ until the strips turned white [20]. The absorbance at 645 and $663 \mathrm{~nm}$ was measured using a spectrophotometer $(\mathrm{V}-1100 \mathrm{D}$, Mapada, China), and the chlorophyll content per unit leaf area $\left(\mathrm{mg} \cdot \mathrm{cm}^{-2}\right)$ was calculated as follows:

$$
\begin{aligned}
& \mathrm{C}(\text { Chla })=\left(12.7 \times \mathrm{A}_{663}-2.69 \times \mathrm{A}_{645}\right) / 2.3079, \\
& \mathrm{C}(\text { Chlb })=\left(22.9 \times \mathrm{A}_{645}-4.86 \times \mathrm{A}_{663}\right) / 2.3079, \\
& \mathrm{C}(\text { Chla }+\mathrm{b})=\mathrm{C}(\text { Chla })+\mathrm{C}(\text { Chlb })
\end{aligned}
$$

\subsection{Soluble Sugar Content}

The soluble sugar content in leaves was determined using the phenol-sulfuric acid method [21]. Leaves (fresh weight $0.4 \mathrm{~g}$ ) were cut into pieces, and extraction was performed in $10 \mathrm{~mL}$ of boiling water for $30 \mathrm{~min}$. After repeated extraction, the volume of the extract was adjusted to $30 \mathrm{~mL}$ with water. The extract was mixed with $9 \%$ phenol, sulfuric acid, and water and then developed for $30 \mathrm{~min}$. At the same time, a standard curve was generated with different concentrations of sucrose solution. The absorbance of the sample and standard solution at $485 \mathrm{~nm}$ was measured using a spectrophotometer to calculate the soluble sugar content $\left(\mathrm{mg} \cdot \mathrm{g}^{-1}\right)$.

\subsection{Real-Time Fluorescence Quantitative PCR (RT-qPCR)}

After the sample was ground in liquid nitrogen, TRIzol reagent (TIANGEN, Beijing, China) and chloroform were added. The sample was then centrifuged and the water phase was taken. Total RNA was extracted used TRIzol reagent. The PrimeScript ${ }^{\mathrm{TM}}$ RT reagent kit with gDNA Eraser (Takara, Japan) was used for RT-PCR. TB Green ${ }^{\circledR}$ Premix Ex Taq ${ }^{\text {TM }}$ II (Takara, Japan) was added to cDNA, and the RT-qPCR reaction was conducted using the CFX96 Real-Time PCR Detection System (Bio-Rad, Hercules, CA, USA). Actin expression was used as the internal reference. The primers were designed using Primer Premier Version 5 (Tab. 1).

Table 1: Primer sequences of the genes for the real-time PCR conducted in the study

\begin{tabular}{llll}
\hline Gene name & Forward primer $\left(5^{\prime}\right.$ - $\left.^{\prime}\right)$ & Reverse primer $\left(5^{\prime}{ }^{\prime} \mathbf{3}^{\prime}\right)$ & Gene ID \\
\hline Actin & TCACTACGACTGCCGAGCGAG & GAGCCACCACTGAGGACAACATTAC & 100282267 \\
$r b c L$ & ATATCTTGGCAGCATTCCGAGTA & TGGTAAGTCCATCAGTCCAAACAG & 845212 \\
$r b c S$ & GATACCCTGCCTCGAGTTCA & CTCCTGCAGCTCCTTGTACA & 100279574 \\
$r c a \beta$ & CTCTTGGAGTACGGACACATGCT & CAGTCTTCATGGCGTCCTCGT & 541712 \\
$P E P C$ & GCCAAGGACATCACTGACGA & GCGCAAGAACTTAGGCACAC & 542372 \\
$G R$ & AGCCAGCCTGATGGTTCAAA & ACCCATCCCCCTCCAGATAG & 541986 \\
$c y F B P a s e$ & GCGAGGAGCAAAAGAAGCTG & AACAGACGCAGTACTTCCCG & 100284739 \\
GAPA & TCAATGCCGACCAGTACAAC & CCTTGATGATGCCGAACTTTTG & 542368 \\
FBPase & CTACGGAGGGATCTACGGGT & AGAATTCTCTGGTGGCCGTC & 100216767 \\
\hline
\end{tabular}


Quantification of mRNA was based on the method described by Livak et al. [22].

\subsection{Enzyme Content and Activity}

The $1 \mathrm{~g}$ leaf samples treated with $0,0.02,0.1,0.5,1.0 \mu \mathrm{M}$ EBR and $4 \mu \mathrm{M} \mathrm{BRZ}$, respectively, were fully ground in liquid nitrogen, added to pre-cooled PBS buffer ( $\mathrm{pH} 7.4$ ), and centrifuged at 8,000 rpm for $30 \mathrm{~min}$, after which the supernatant was tested using an ELISA kit (Mskbio, Hunan, China). The supernatant and HRP-labeled detection antibody were added to the coated microwells pre-coated with enzyme capture antibody, incubated, and washed thoroughly. The color was developed with the use of the substrate tetramethylbenzidine (TMB). An enzyme-labeled instrument (Thermo Fisher Scientific, Waltham, MA, USA) was used to determine the absorbance of standard products and samples at $450 \mathrm{~nm}$ in order to calculate the content and activity of dark reaction enzymes in the samples.

\subsection{Statistical Analysis}

The data represent the means of three biological replicates. The significance analysis between different treatments was performed using the Tukey's test using the statistical software Statistical Product and Service Solutions (SPSS).

\section{Results}

\subsection{Determination of Chlorophyll Content}

Treatment with exogenous EBR at $0.05,0.2$, and $0.5 \mu \mathrm{M}$ for $24 \mathrm{~h}$ significantly increased the chlorophyll $\mathrm{a}$ and chlorophyll $(\mathrm{a}+\mathrm{b})$ content as compared to those in the control, whereas the exogenous BRZ treatment for $24 \mathrm{~h}$ significantly reduced the chlorophyll a content (Tab. 2). The $48 \mathrm{~h}$ EBR and BRZ treatments resulted in no significant changes in the chlorophyll content of maize seedlings (Tab. 2). In order to understand the effect of different concentrations and durations of EBR application on the chlorophyll content of detached maize seedling leaves, the chlorophyll content of detached maize leaves under different treatments was determined. Soaking at $0.2 \mu \mathrm{M}$ EBR for $6 \mathrm{~h}$ can significantly increase the chlorophyll a content, whereas 0.1 and $0.2 \mu \mathrm{M}$ EBR treatments for $24 \mathrm{~h}$ can significantly increase the content of chlorophyll a and chlorophyll b (Tab. 2).

Table 2: Chlorophyll content in maize leaves subjected to EBR and BRZ treatments. Chl, chlorophyll. Significant differences were analyzed using the Tukey's test $(P<0.05)$. Three biological replicates; data are expressed as mean $\pm \mathrm{SE}$

\begin{tabular}{|c|c|c|c|c|c|}
\hline $\begin{array}{l}\text { Leaf } \\
\text { condition }\end{array}$ & Time & Treatment & Chl a content $\left(\mathrm{mg} \cdot \mathrm{cm}^{-2}\right)$ & $\mathrm{Chl} \mathrm{b}$ content $\left(\mathrm{mg} \cdot \mathrm{cm}^{-2}\right)$ & $\mathrm{Chl} \mathrm{a}+\mathrm{b}\left(\mathrm{mg} \cdot \mathrm{cm}^{-2}\right)$ \\
\hline \multirow[t]{12}{*}{ Living } & $24 \mathrm{~h}$ & $\mathrm{BRZ}$ & $1.36 \pm 0.13^{\mathrm{c}}$ & $0.72 \pm 0.04^{\mathrm{ab}}$ & $2.08 \pm 0.02^{\mathrm{d}}$ \\
\hline & & Control & $1.61 \pm 0.01^{\mathrm{a}}$ & $0.67 \pm 0.06^{\mathrm{ac}}$ & $2.28 \pm 0.07^{\mathrm{a}}$ \\
\hline & & $0.05 \mu \mathrm{M}$ EBR & $1.84 \pm 0.03^{b}$ & $0.60 \pm 0.02^{\mathrm{c}}$ & $2.44 \pm 0.02^{\mathrm{bc}}$ \\
\hline & & $0.10 \mu \mathrm{M}$ EBR & $1.61 \pm 0.04^{\mathrm{a}}$ & $0.72 \pm 0.03^{\mathrm{ab}}$ & $2.33 \pm 0.04^{\mathrm{ab}}$ \\
\hline & & $0.20 \mu \mathrm{M}$ EBR & $1.87 \pm 0.03^{b}$ & $0.63 \pm 0.02^{\mathrm{ac}}$ & $2.50 \pm 0.06^{\mathrm{c}}$ \\
\hline & & $0.50 \mu \mathrm{M}$ EBR & $1.65 \pm 0.04^{\mathrm{a}}$ & $0.79 \pm 0.03^{b}$ & $2.45 \pm 0.06^{b c}$ \\
\hline & $48 \mathrm{~h}$ & $\mathrm{BRZ}$ & $1.74 \pm 0.02^{\mathrm{ab}}$ & $0.60 \pm 0.06^{\mathrm{a}}$ & $2.34 \pm 0.06^{\mathrm{c}}$ \\
\hline & & Control & $1.80 \pm 0.13^{\mathrm{abc}}$ & $0.62 \pm 0.12^{\mathrm{a}}$ & $2.42 \pm 0.13^{\mathrm{ac}}$ \\
\hline & & $0.05 \mu \mathrm{M}$ EBR & $1.74 \pm 0.02^{\mathrm{a}}$ & $0.71 \pm 0.02^{\mathrm{a}}$ & $2.44 \pm 0.07^{\mathrm{abc}}$ \\
\hline & & $0.10 \mu \mathrm{M}$ EBR & $1.94 \pm 0.01^{\mathrm{c}}$ & $0.66 \pm 0.00^{\mathrm{a}}$ & $2.60 \pm 0.01^{\mathrm{b}}$ \\
\hline & & $0.20 \mu \mathrm{M}$ EBR & $1.89 \pm 0.04^{\mathrm{bc}}$ & $0.66 \pm 0.01^{\mathrm{a}}$ & $2.55 \pm 0.01^{\mathrm{ab}}$ \\
\hline & & $0.50 \mu \mathrm{M}$ EBR & $1.90 \pm 0.02^{\mathrm{c}}$ & $0.64 \pm 0.05^{\mathrm{a}}$ & $2.54 \pm 0.01^{\mathrm{ab}}$ \\
\hline
\end{tabular}




\begin{tabular}{|c|c|c|c|c|c|}
\hline $\begin{array}{l}\text { Leaf } \\
\text { condition }\end{array}$ & Time & Treatment & Chl a content $\left(\mathrm{mg} \cdot \mathrm{cm}^{-2}\right)$ & $\mathrm{Chl} \mathrm{b}$ content $\left(\mathrm{mg} \cdot \mathrm{cm}^{-2}\right)$ & $\mathrm{Chl} \mathrm{a+b}\left(\mathrm{mg} \cdot \mathrm{cm}^{-2}\right)$ \\
\hline \multirow[t]{21}{*}{ Detached } & \multirow[t]{7}{*}{$6 \mathrm{~h}$} & $\mathrm{BRZ}$ & $1.84 \pm 0.02^{b}$ & $0.60 \pm 0.02^{b}$ & $2.44 \pm 0.04^{b}$ \\
\hline & & Control & $1.72 \pm 0.06^{\mathrm{a}}$ & $0.54 \pm 0.01^{\mathrm{ab}}$ & $2.26 \pm 0.05^{\mathrm{a}}$ \\
\hline & & $0.02 \mu \mathrm{M}$ EBR & $1.76 \pm 0.42^{\mathrm{abc}}$ & $0.57 \pm 0.11^{\mathrm{ab}}$ & $2.33 \pm 0.53^{\mathrm{abc}}$ \\
\hline & & $0.05 \mu \mathrm{M}$ EBR & $1.75 \pm 0.03^{\mathrm{ab}}$ & $0.56 \pm 0.05^{\mathrm{ab}}$ & $2.31 \pm 0.02^{\mathrm{a}}$ \\
\hline & & $0.10 \mu \mathrm{M}$ EBR & $1.68 \pm 0.15^{\mathrm{abc}}$ & $0.55 \pm 0.05^{\mathrm{ab}}$ & $2.23 \pm 0.21^{\mathrm{abc}}$ \\
\hline & & $0.20 \mu \mathrm{M}$ EBR & $1.54 \pm 0.03^{\mathrm{c}}$ & $0.48 \pm 0.04^{\mathrm{a}}$ & $2.02 \pm 0.05^{\mathrm{c}}$ \\
\hline & & $0.50 \mu \mathrm{M}$ EBR & $1.58 \pm 0.21^{\mathrm{abc}}$ & $0.48 \pm 0.05^{\mathrm{ab}}$ & $2.07 \pm 0.26^{\mathrm{abc}}$ \\
\hline & \multirow[t]{7}{*}{$12 \mathrm{~h}$} & $\mathrm{BRZ}$ & $2.38 \pm 0.04^{\mathrm{b}}$ & $0.79 \pm 0.05^{\mathrm{c}}$ & $3.51 \pm 0.03^{\mathrm{b}}$ \\
\hline & & Control & $1.99 \pm 0.42^{\mathrm{a}}$ & $0.63 \pm 0.11^{\mathrm{ab}}$ & $2.62 \pm 0.53^{\mathrm{a}}$ \\
\hline & & $0.02 \mu \mathrm{M}$ EBR & $2.08 \pm 0.11^{\mathrm{a}}$ & $0.64 \pm 0.05^{\mathrm{abc}}$ & $2.72 \pm 0.15^{\mathrm{a}}$ \\
\hline & & $0.05 \mu \mathrm{M}$ EBR & $2.20 \pm 0.02^{\mathrm{a}}$ & $0.66 \pm 0.02^{\mathrm{abc}}$ & $2.86 \pm 0.04^{\mathrm{a}}$ \\
\hline & & $0.10 \mu \mathrm{M}$ EBR & $2.15 \pm 0.15^{\mathrm{a}}$ & $0.73 \pm 0.06^{\mathrm{bc}}$ & $2.88 \pm 0.21^{\mathrm{ab}}$ \\
\hline & & $0.20 \mu \mathrm{M}$ EBR & $1.95 \pm 0.01^{\mathrm{a}}$ & $0.61 \pm 0.04^{\mathrm{ab}}$ & $2.56 \pm 0.04^{\mathrm{a}}$ \\
\hline & & $0.50 \mu \mathrm{M}$ EBR & $2.05 \pm 0.14^{\mathrm{a}}$ & $0.57 \pm 0.01^{\mathrm{a}}$ & $2.62 \pm 0.15^{\mathrm{a}}$ \\
\hline & \multirow[t]{7}{*}{$24 \mathrm{~h}$} & BRZ & $2.29 \pm 0.01^{\mathrm{c}}$ & $0.77 \pm 0.10^{\mathrm{c}}$ & $3.05 \pm 0.10^{\mathrm{c}}$ \\
\hline & & Control & $1.56 \pm 0.09^{\mathrm{a}}$ & $0.55 \pm 0.03^{\mathrm{ab}}$ & $2.11 \pm 0.12^{\mathrm{a}}$ \\
\hline & & $0.02 \mu \mathrm{M}$ EBR & $1.59 \pm 0.04^{\mathrm{a}}$ & $0.58 \pm 0.01^{\mathrm{ab}}$ & $2.17 \pm 0.05^{\mathrm{a}}$ \\
\hline & & $0.05 \mu \mathrm{M}$ EBR & $1.56 \pm 0.02^{\mathrm{a}}$ & $0.54 \pm 0.01^{\mathrm{ab}}$ & $2.10 \pm 0.02^{\mathrm{ad}}$ \\
\hline & & $0.10 \mu \mathrm{M}$ EBR & $1.39 \pm 0.04^{\mathrm{d}}$ & $0.49 \pm 0.01^{\mathrm{a}}$ & $1.88 \pm 0.05^{\mathrm{d}}$ \\
\hline & & $0.20 \mu \mathrm{M}$ EBR & $1.78 \pm 0.04^{\mathrm{b}}$ & $0.61 \pm 0.01^{\mathrm{b}}$ & $2.39 \pm 0.05^{\mathrm{b}}$ \\
\hline & & $0.50 \mu \mathrm{M}$ EBR & $1.48 \pm 0.08^{\mathrm{ad}}$ & $0.53 \pm 0.03^{\mathrm{ab}}$ & $2.01 \pm 0.10^{\mathrm{ad}}$ \\
\hline
\end{tabular}

\subsection{Changes in Soluble Sugar Content}

With increasing EBR concentration, the soluble sugar content of maize seedlings treated with $0.1,0.2$, and $0.5 \mu \mathrm{M}$ EBR for $24 \mathrm{~h}$ were $35.4 \%, 32 \%$, and $36.9 \%$ higher, respectively, than that in the control group. With the extension of the treatment time, the soluble sugar content significantly increased after treatment with $0.1 \mu \mathrm{M}$ EBR (Fig. 1).

\subsection{Dark-Reaction-Related Enzyme Coding Gene Expression}

In order to understand the regulatory effect of EBR on the carbon-fixation reaction of plants in different forms, we analyzed the effect of different concentrations of EBR on the expression of enzymes related to the carbon-fixation reaction in maize seedlings. After $24 \mathrm{~h}$ of spraying maize seedlings with $0.1 \mu \mathrm{M} \mathrm{EBR}$, the transcription levels of glyceraldehyde-3-phosphate dehydrogenase subunit A (GAPA), cytoplasmic FBPase (cyFBPase), ribulose-1,5-bisphosphate carboxylase small subunit ( $\mathrm{rbcS}$ ), phosphoenolpyruvate carboxylase (PEPC), fructose-1,6-bisphosphatase (FBPase), Rubisco activase $\beta$ subunit (RCAß), ribulosel,5-bisphosphate carboxylase large subunit (rbcL), and glutathione reductase (GR) were 96.8\%, 48.4\%, $79.3 \%, 41 \%, 85.6 \%, 133.3 \%, 68.8 \%$, and $119.8 \%$ higher, respectively, in the $0.1 \mu \mathrm{M}$ EBR treatment group than in the control group. However, the expression of these enzyme coding genes was significantly inhibited by the $1 \mu \mathrm{M}$ EBR and $4 \mu \mathrm{M} \mathrm{BRZ}$ treatments (Figs. 2 and 3). 

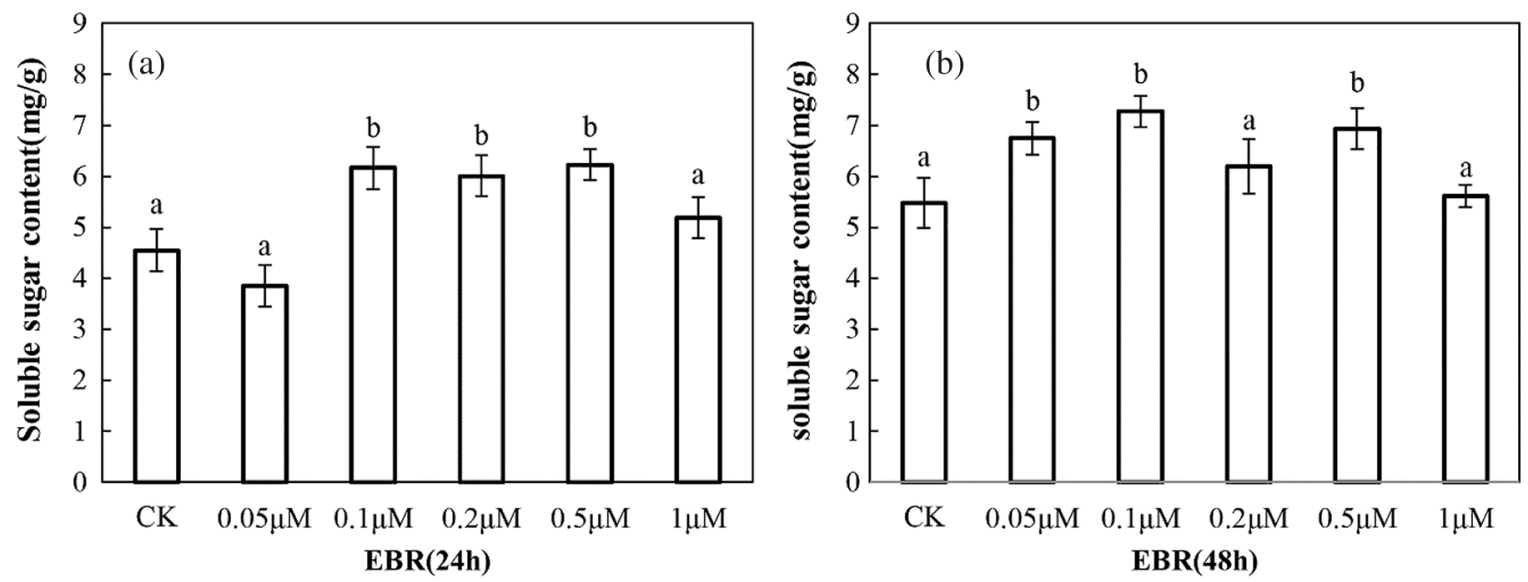

Figure 1: Soluble sugar content in young maize leaves sprayed with various concentration of EBR after $24 \mathrm{~h}$ (a) and $48 \mathrm{~h}$ (b). Significant differences were analyzed using Tukey's test $(P<0.05)$. Three biological replicates; data are expressed as mean $\pm \mathrm{SE}$

To understand the effect of short-term continuous treatment with a small amount of EBR on the dark reaction of detached maize leaves, the expression levels of the enzyme coding genes was determined. The transcription levels of GAPDH, cyFBPase, PEPC, FBPase, rcaß, rcaL, and GR were increased by $71.9 \%$, $49.3 \%, 48.3 \%, 85.9 \%, 69.5 \%, 41.5 \%$, and $52.7 \%$, respectively, after $6 \mathrm{~h}$ of $0.2 \mu \mathrm{M}$ EBR treatment (Fig. 3). Moreover, $r b c S$ expression was $15.6 \%$ higher in detached leaves treated with $0.1 \mu \mathrm{M}$ EBR (Fig. 3).

Plants were treated with BRZ in order to understand the effect of inhibition of EBR synthesis on the dark reaction. After $24 \mathrm{~h}$ of BRZ treatment, maize seedlings showed a reduced expression of GAPDH, cyFBPase, $P E P C, F B P a s e, R C A \beta, r c a L$, and $G R$, but this inhibitory effect was not obvious in the isolated leaves (Fig. 3). Maize leaf protoplasts were used as experimental materials to understand the effect of EBR on the dark reaction. The results showed that the expression levels of $P E P C, r c a \beta$, and $r b c L$ in maize protoplast were increased by $74 \%, 136.9 \%$, and $120 \%$, respectively, with $0.1 \mathrm{nM}$ EBR treatment (Fig. 4). The concentration of EBR needed to promote the dark reaction in protoplasts was lower than the corresponding concentration in the leaves.

\subsection{Carbon Fixation-Related Enzyme Contents and Activities}

Studies have shown that BRs can influence the enzyme activity of carbon fixation in a variety of plants [8]. In this study, we determined the enzyme content of maize seedlings sprayed with EBR. The results showed that the content of GR and Rubisco increased by $34 \%$ and $32.7 \%$, respectively, in $0.02 \mu \mathrm{M}$ EBR, and the contents of FBPase and RCA were $32.7 \%$ and $68.5 \%$ higher, respectively, in the $0.1 \mu \mathrm{M}$ EBR group than in the control (Fig. 5). The activity levels of GAPDH, GR, and PEPC were enhanced by $27.6 \%, 117.9 \%$, and $62.2 \%$, respectively, under $0.5 \mu \mathrm{M}$ EBR, and the activity of RCA and Rubisco were elevated by $53.4 \%$ and $28.7 \%$, respectively, under $0.1 \mu \mathrm{M}$ EBR treatment (Fig. 5). In contrast, the application of BRZ suppressed the synthesis of BRs in plants and reduced GAPDH activity. Investigating the different concentrations of EBR, the trend of RCA content and activity is basically the same; however, such consistency is not reflected in several other dark-reaction-related enzymes, which could be attributed to protein modification. 
GAPA
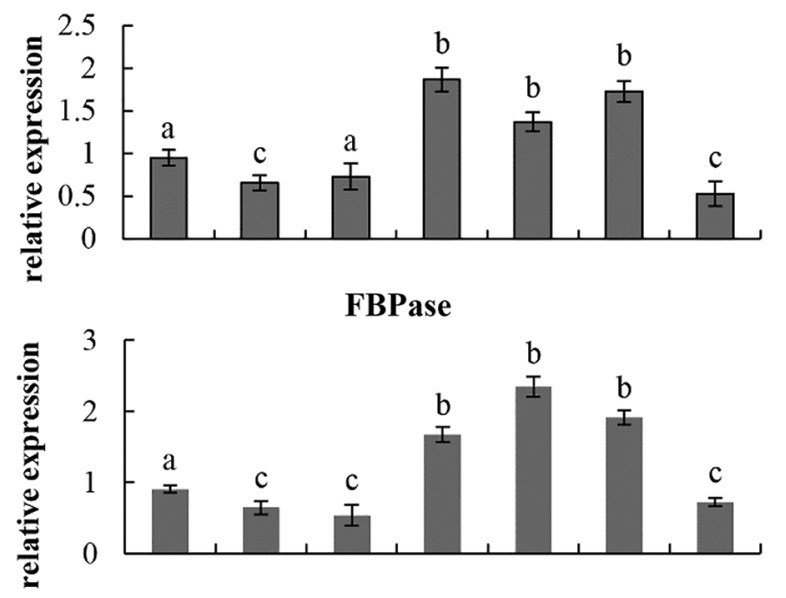

rbcL
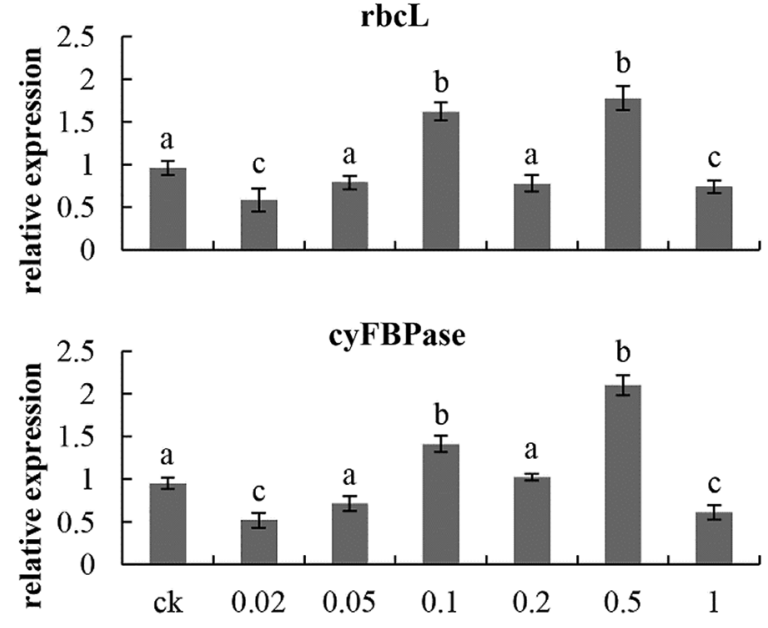

RCAB

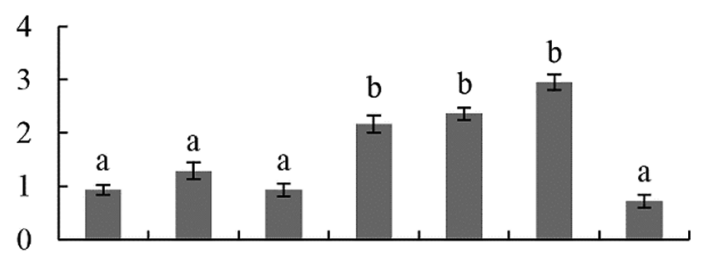

PEPC

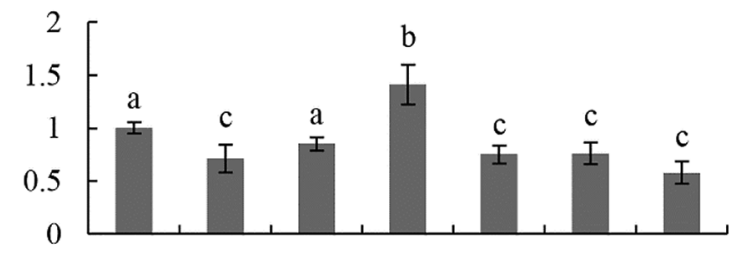

rbcS

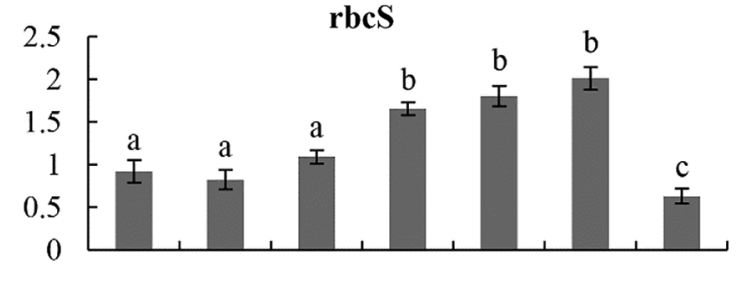

GR

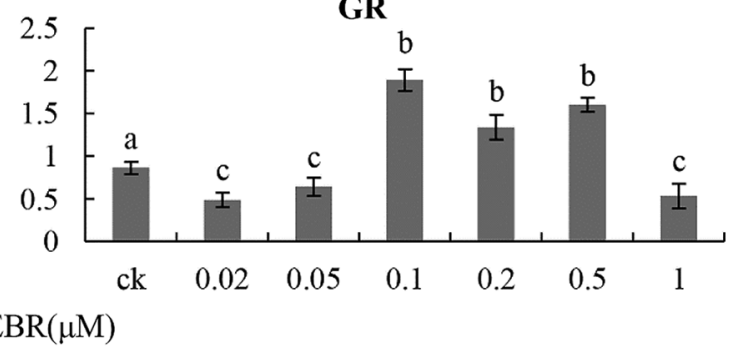

Figure 2: Transcriptional level of dark reaction-related enzyme coding genes in young maize leaves sprayed with various concentrations of EBR. GAPA, glyceraldehyde-3-phosphate dehydrogenase subunit A; rbcS, ribulose-l,5-bisphosphate carboxylase small subunit; FBPase, fructose-1,6-bisphosphatase); RCA , Rubisco activase subunit $\beta$; GR, glutathione reductase; cyFBPase, cytoplasmic FBPase; PEPC, phosphoenolpyruvate carboxylase; rbcL, ribulose-l,5-bisphosphate carboxylase large subunit. Significant differences were analyzed using the Tukey's test $(P<0.05)$. Three biological replicates; data are expressed as mean $\pm \mathrm{SE}$

\section{Discussion}

Chlorophyll is a photosynthetic pigment that converts photons into electrons. BRs affect chlorophyll synthesis, and mutations in biosynthesis genes negatively regulate chlorophyll synthesis and affect crop yield [23]. Spraying EBR on maize seedlings can improve the chlorophyll content after $24 \mathrm{~h}$, and the same improvement occurs in the chlorophyll $\mathrm{a}$ and $\mathrm{b}$ contents of separated leaves after continuous treatment with EBR. Interestingly, BRZ treatment of living maize leaves reduced the chlorophyll content, which is contrary to the results in cucumber [24]. We speculate that the possible reason for this phenomenon is that the short-term treatment of BRZ has an inhibitory effect on BRs, causing a reduction in chlorophyll content. The chlorophyll content of detached maize leaves treated with continuous BRZ 
increased significantly. This is similar to the effect obtained with the BR biosynthesis defective mutant deetiolated2 (det2) with dark-green leaves, which is insensitive to plant chlorophyll accumulation but showed increased chl content after BRZ sprinkling in wild-type Arabidopsis [25].

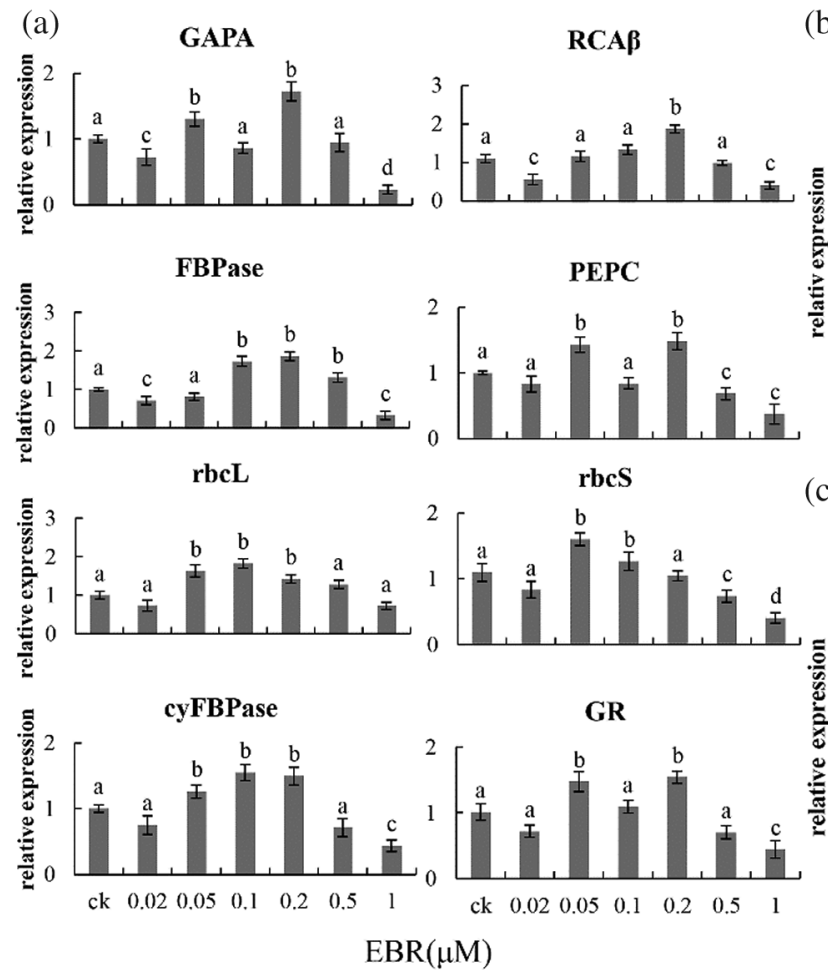

(b)

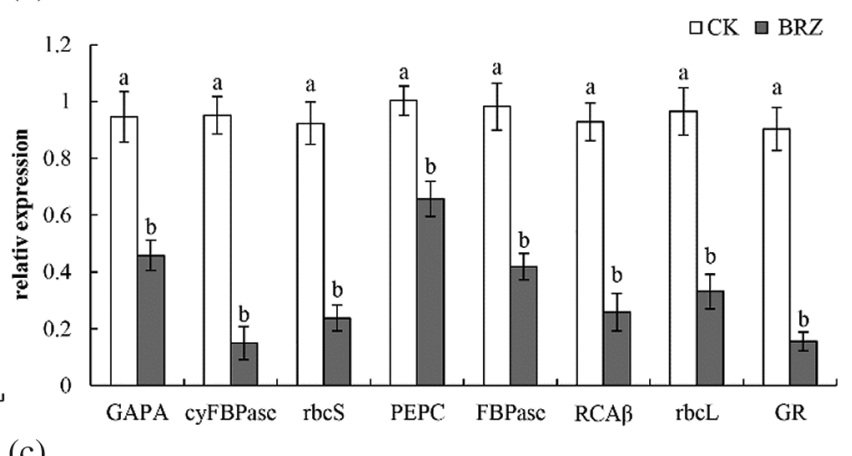

(c)

Figure 3: Effect of EBR and BRZ on transcriptional level of dark-reaction enzyme coding genes in detached leaf maize leaves soaked continuously in EBR after $6 \mathrm{~h}$ (a), young maize leaves after $24 \mathrm{~h}$ of BRZ treatment (b), detached leaves after $6 \mathrm{~h}$ of BRZ treatment (c). Full gene names are given in Fig. 2. Significant differences were analyzed using the Tukey's test $(P<0.05)$. Three biological replicates; data are expressed as mean $\pm \mathrm{SE}$
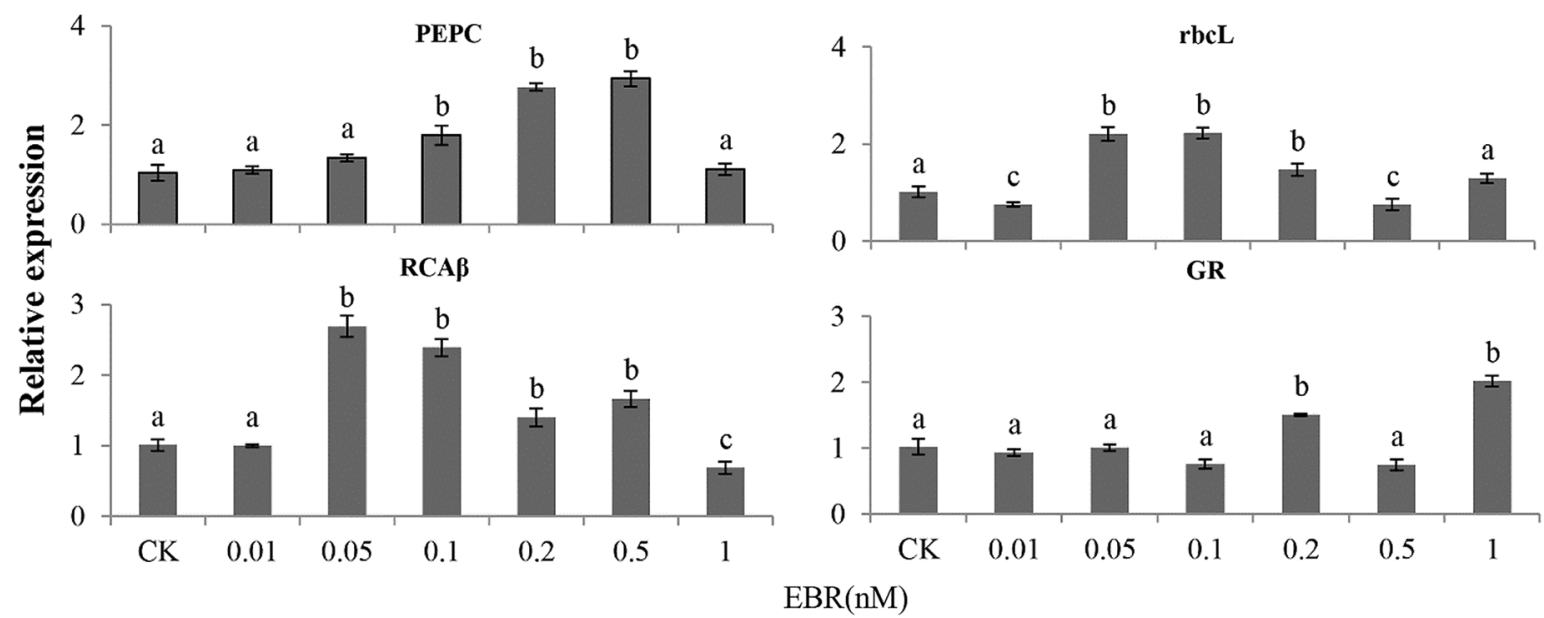

Figure 4: Transcriptional level of dark-reaction-related enzyme coding genes in leaf protoplast of maize cultured in different concentrations of EBR. Full gene names are given in Fig. 2. Significant differences were analyzed using the Tukey's test $(P<0.05)$. Three biological replicates; data are expressed as mean $\pm \mathrm{SE}$ 

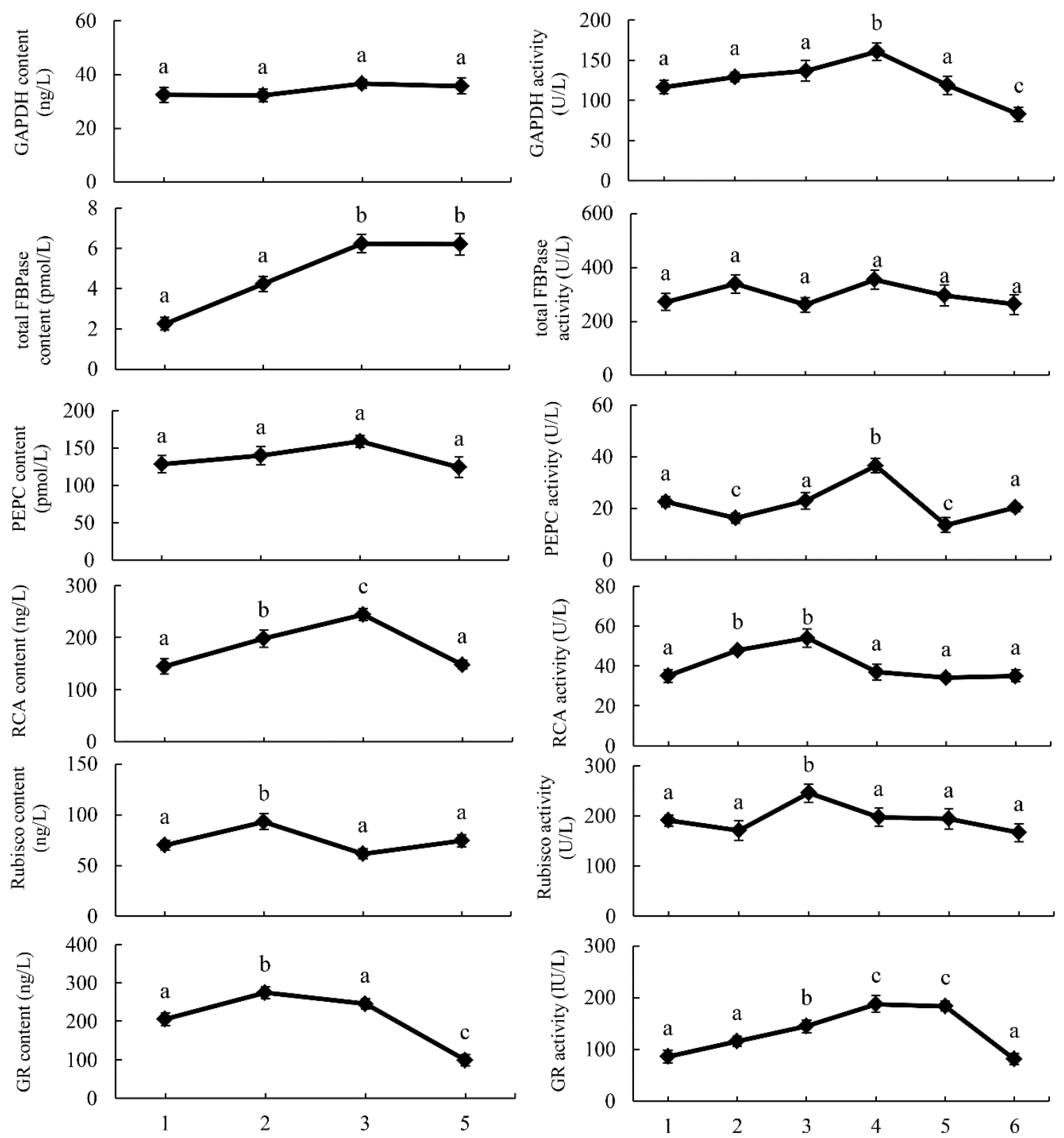

Figure 5: The content and activity of GAPDH, PEPC, Rubisco, $R C A$, and $G R$ in maize leaves treated with various EBR concentrations: 1, control; 2, $0.02 \mu \mathrm{M}$ EBR; 3, $0.1 \mu \mathrm{M}$ EBR; 4, $0.5 \mu \mathrm{M}$ EBR; 5, $1 \mu \mathrm{M} \mathrm{EBR;} 6$, $4 \mu \mathrm{M}$ BRZ. Significant differences were analyzed using the Tukey's test $(P<0.05)$. Three biological replicates; data are expressed as mean $\pm \mathrm{SE} ; \mathrm{n}=3$

Photosynthesis is related to the production of carbohydrates, and the transportation of sugars affects maize yield [26]. The accumulation of soluble sugar content, the main form of carbohydrate metabolism and temporary storage in plants, is accelerated by BRs in maize, which is consistent with the effect of BRs on sugar content in grapes, which worked by promoting the activities of invertases (acidic and neutral) and sucrose synthase (sucrolytic) [27]. 
In the dark reaction, Rubisco determines the net photosynthetic rate of plants, and it is the key enzyme catalyzing the initial steps of $\mathrm{CO}_{2}$ fixation and photorespiration. Rubisco activity can be activated by RCA, the expression of which affects maize yield [28]. Additionally, the activities of RCA and Rubisco are similar in their degree of sensitivity to changes in external factors [29]. Our results showed that both reached a peak of activity at the same time after $0.1 \mu \mathrm{M}$ EBR treatment. In the dark reaction, FBPase regulates the accumulation of carbohydrates, whereas cyFBPase is a crucial part of gluconeogenesis and participates in the renewal ability of the Calvin cycle. In this experiment, the expression of the genes FBPase and cyFBPase, as well as total FBPase content, was facilitated by EBR, but total FBPase activity was not enhanced under EBR treatment, presumably because an increase in the protein content was not activated [30]. In the dark reaction, the overexpression of $P E P C$, catalyzing $\mathrm{CO}_{2}$ fixation in the carbon assimilation process of $\mathrm{C}_{4}$ plants, increased photosynthetic carbon assimilation per leaf area [31]. In this study, the activity of PEPC can be regulated by EBR treatment, and similar results have also been reported in rice [10] and soybean [32]. In addition, we found that BR also modulated GAPA expression, which is the subunit of chloroplast GAPDH in the reduction phase of the Calvin cycle. The catalytic function of GR maintains the normal ratio of GSH/GSSG and the redox balance in plant cells. EBR can promote GR activity by increasing the GSH/GSSG ratio to induce the carbon-fixation reaction [33]. The expression of carbon reaction-related enzyme coding genes in this study is not only enhanced by EBR but also inhibited by BRZ; this phenomenon also occurs in cucumber plants [13]. The physiological characteristics of freshly isolated protoplasts and leaves are similar, and the disappearance of the cell wall makes the cell more sensitive to the external environment [34]. EBR also functions in isolated plant cells. The expression of key dark-reaction enzymes in the protoplasts increased significantly under $0.1 \mathrm{~nm}$ EBR treatment, which is similar to the effect of EBR on the dark reaction of maize leaves.

In addition, we compared the changes in gene expression and activity of carbon fixation-related enzymes after treatment with different concentrations of EBR in living maize leaves and found that although gene expression, protein content, and enzyme activity are clearly regulated by EBR, but the trends are inconsistent. This inconsistency was attributed to the fact that the abundance of the transcript itself was not always sufficient to predict protein levels [35], and the enhancement of protein content was not in its activation state [36].

The results of our study demonstrate that a lower concentration of EBR can affect the chlorophyll and soluble sugar content and the expression of dark-reaction enzymes in maize seedlings. The transcription level of dark-reaction enzymes steadily increased by $40 \%$ to $100 \%$ under $0.1 \mu \mathrm{M}$ EBR treatment, in which soluble sugar content was elevated by $33 \%$. Conversely, BRZ can affect the content of chlorophyll and inhibit the expression of certain genes, but the inhibition of enzyme activity was not obvious. It was also shown that EBR can regulate gene expression in different forms of maize leaves, such as in vitro leaves and protoplasts.

Acknowledgement: The authors would like to thank Hui Li for his assistance.

Funding Statement: The project was supported by the National Natural Science Foundation of China (Nos. 31771702 and 31571682).

Conflicts of Interest: This article does not contain any studies involving animals or human participants as research subjects. The authors declare that they have no conflicts of interest to report regarding the present study.

\section{References}

1. Ort, D. R., Merchant, S. S., Alric, J., Barkan, A., Blankenship, R. E. et al. (2015). Redesigning photosynthesis to sustainably meet global food and bioenergy demand. Proceedings of the National Academy of Sciences of the United States of America, 112(28), 8529-8536. DOI 10.1073/pnas.1424031112.

2. Long, S. P., Zhu, X. G., Naidu, S. L., Ort, D. R. (2006). Can improvement in photosynthesis increase crop yields? Plant Cell and Environment, 29(3), 315-330. DOI 10.1111/j.1365-3040.2005.01493.x. 
3. Nowicka, B., Ciura, J., Szymanska, R., Kruk, J. (2018). Improving photosynthesis, plant productivity and abiotic stress tolerance-current trends and future perspectives. Journal of Plant Physiology, 231, 415-433. DOI 10.1016/j. jplph.2018.10.022.

4. Cotton, C. A. R., Edlich-Muth, C., Bar-Even, A. (2018). Reinforcing carbon fixation: $\mathrm{CO}_{2}$ reduction replacing and supporting carboxylation. Current Opinion in Biotechnology, 49, 49-56. DOI 10.1016/j.copbio.2017.07.014.

5. Bajguz, A., Tretyn, A. (2003). The chemical characteristic and distribution of brassinosteroids in plants. Phytochemistry, 62(7), 1027-1046. DOI 10.1016/S0031-9422(02)00656-8.

6. Singh, A., Breja, P., Khurana, J. P., Khurana, P. (2016). Wheat brassinosteroid-insensitivel (TaBRI1) interacts with members of TaSERK gene family and cause early flowering and seed yield enhancement in Arabidopsis. PLoS One, 11(6), e0153273. DOI 10.1371/journal.pone.0153273.

7. Clouse, S. D. (2011). Brassinosteroid signal transduction: From receptor kinase activation to transcriptional networks regulating plant development. Plant Cell, 23(4), 1219-1230. DOI 10.1105/tpc.111.084475.

8. Siddiqui, H., Hayat, S., Bajguz, A. (2018). Regulation of photosynthesis by brassinosteroids in plants. Acta Physiologiae Plantarum, 40(3), 334. DOI 10.1007/s11738-018-2639-2.

9. Wu, C. Y., Trieu, A., Radhakrishnan, P., Kwok, S. F., Harris, S. et al. (2008). Brassinosteroids regulate grain filling in rice. Plant Cell, 20(8), 2130-2145. DOI 10.1105/tpc.107.055087.

10. Zhang, M. C., Zhai, Z. X., Tian, X. L., Duan, L. S., Li, Z. H. (2008). Brassinolide alleviated the adverse effect of water deficits on photosynthesis and the antioxidant of soybean (Glycine max L.). Plant Growth Regulation, 56(3), 257-264. DOI 10.1007/s10725-008-9305-4.

11. Siddiqui, H., Ahmed, K. B. M., Hayat, S. (2018). Comparative effect of 28-homobrassinolide and 24-epibrassinolide on the performance of different components influencing the photosynthetic machinery in Brassica juncea L. Plant Physiology and Biochemistry, 129(2), 198-212. DOI 10.1016/j.plaphy.2018.05.027.

12. Efimova, M. V., Vankova, R., Kusnetsov, V. V., Litvinovskaya, R. P., Zlobin, I. E. et al. (2017). Effects of 24-epibrassinolide and green light on plastid gene transcription and cytokinin content of barley leaves. Steroids, 120(1949), 32-40. DOI 10.1016/j.steroids.2016.12.004.

13. Jiang, Y. P., Cheng, F., Zhou, Y. H., Xia, X. J., Mao, W. H. et al. (2012). Brassinosteroid-induced $\mathrm{CO}_{2}$ assimilation is associated with increased stability of redox-sensitive photosynthetic enzymes in the chloroplasts in cucumber plants. Biochemical and Biophysical Research Communications, 426(3), 390-394. DOI 10.1016/j. bbrc.2012.08.100.

14. Li, X. J., Guo, X., Zhou, Y. H., Shi, K., Zhou, J. et al. (2016). Overexpression of a brassinosteroid biosynthetic gene Dwarf enhances photosynthetic capacity through activation of Calvin cycle enzymes in tomato. BMC Plant Biology, 16(1), 71. DOI 10.1186/s12870-015-0700-5.

15. Zheng, L. W., Ma, J. H., Zhang, L. Z., Gao, C., Zhang, D. et al. (2018). Revealing critical mechanisms of BR-mediated apple nursery tree growth using iTRAQ-based proteomic analysis. Journal of Proteomics, 173, 139-154. DOI 10.1016/j.jprot.2017.12.007.

16. Salesse-Smith, C. E., Sharwood, R. E., Busch, F. A., Kromdijk, J., Bardal, V. et al. (2018). Overexpression of Rubisco subunits with RAF1 increases Rubisco content in maize. Nature Plants, 4(10), 802-810. DOI 10.1038/s41477-018-0252-4.

17. Makarevitch, I., Thompson, A., Muehlbauer, G. J., Springer, N. M. (2012). Brdl gene in maize encodes a brassinosteroid C-6 oxidase. PLoS One, 7(1), e30798. DOI 10.1371/journal.pone.0030798.

18. Rothova, O., Hola, D., Kocova, M., Tumova, L., Hnilicka, F. et al. (2014). 24-Epibrassinolide and 20-hydroxyecdysone affect photosynthesis differently in maize and spinach. Steroids, 85, 44-57. DOI 10.1016/ j.steroids.2014.04.006.

19. Yoo, S. D., Cho, Y. H., Sheen, J. (2007). Arabidopsis mesophyll protoplasts: a versatile cell system for transient gene expression analysis. Nature Protocols, 274(7), 1565-1572. DOI 10.1038/nprot.2007.199.

20. Perez-Patricio, M., Camas-Anzueto, J. L., Sanchez-Alegria, A., Aguilar-Gonzalez, A., Gutierrez-Miceli, F. et al. (2018). Optical method for estimating the chlorophyll contents in plant leaves. Sensors, 18(2), 650-662. DOI $10.3390 / \mathrm{s} 18020650$. 
21. Rao, P., Pattabiraman, T. N. (1989). Reevaluation of the phenol-sulfuric acid reaction for the estimation of hexoses and pentoses. Analytical Biochemistry, 181(1), 18-22. DOI 10.1016/0003-2697(89)90387-4.

22. Livak, K. J., Schmittgen, T. D. (2001). Analysis of relative gene expression data using real-time quantitative PCR. Methods, 25(4), 402-408. DOI 10.1006/meth.2001.1262.

23. Kume, A., Akitsu, T., Nasahara, K. N. (2018). Why is chlorophyll b only used in light-harvesting systems? Journal of Plant Research, 131(6), 961-972. DOI 10.1007/s10265-018-1052-7.

24. Ahammed, G. J., He, B. B., Qian, X. J., Zhou, Y. H., Shi, K. et al. (2017). 24-Epibrassinolide alleviates organic pollutants-retarded root elongation by promoting redox homeostasis and secondary metabolism in Cucumis sativus L. Environmental Pollution, 229, 922-931. DOI 10.1016/j.envpol.2017.07.076.

25. Yoshizawa, E., Kaizuka, M., Yamagami, A., Higuchi-Takeuchi, M., Matsui, M. et al. (2014). BPG3 is a novel chloroplast protein that involves the greening of leaves and related to brassinosteroid signaling. Bioscience, Biotechnology, and Biochemistry, 78(3), 420-429. DOI 10.1080/09168451.2014.885831.

26. Best, N. B., Hartwig, T., Budka, J., Fujioka, S., Johal, G. et al. (2016). nana plant2 encodes a maize ortholog of the Arabidopsis brassinosteroid biosynthesis gene DWARF1, identifying developmental interactions between brassinosteroids and gibberellins. Plant Physiology, 171(4), 2633-2647. DOI 10.1104/pp.16.00399.

27. Xu, F., Xi, Z. M., Zhang, H., Zhang, C. J., Zhang, Z. W. (2015). Brassinosteroids are involved in controlling sugar unloading in Vitis vinifera 'Cabernet Sauvignon' berries during veraison. Plant Physiology and Biochemistry, 94(3), 197-208. DOI 10.1016/j.plaphy.2015.06.005.

28. Zhang, Y., Zhou, Y., Sun, Q., Deng, D., Liu, H. et al. (2019). Genetic determinants controlling maize rubisco activase gene expression and a comparison with rice counterparts. BMC Plant Biology, 19(1), 351-364. DOI 10.1186/s12870-019-1965-x.

29. Jensen, R. G. (2000). Activation of Rubisco regulates photosynthesis at high temperature and $\mathrm{CO}_{2}$. Proceedings of the National Academy of Sciences of the United States of America, 97(24), 12937-12938. DOI 10.1073/ pnas.97.24.12937.

30. Daie, J. (1993). Cytosolic fructose-1,6-bisphosphatase: A key enzyme in the sucrose biosynthetic pathway. Photosynthesis Research, 38(1), 5-14. DOI 10.1007/BF00015056.

31. Kandoi, D., Mohanty, S., Govindjee, Tripathy, B. C. (2016). Towards efficient photosynthesis: overexpression of Zea mays phosphoenolpyruvate carboxylase in Arabidopsis thaliana. Photosynthesis Research, 130(1-3), 47-72. DOI 10.1007/s11120-016-0224-3.

32. Zhang, M., Zhai, Z., Tian, X., Duan, L., Li, Z. (2008). Brassinolide alleviated the adverse effect of water deficits on photosynthesis and the antioxidant of soybean (Glycine max L.). Plant Growth Regulation, 56(3), 257-264. DOI 10.1007/s10725-008-9305-4.

33. Jiang, Y. P., Cheng, F., Zhou, Y. H., Xia, X. J., Mao, W. H. et al. (2012). Cellular glutathione redox homeostasis plays an important role in the brassinosteroid-induced increase in $\mathrm{CO}_{2}$ assimilation in Cucumis sativus. New Phytologist, 194(4), 932-943. DOI 10.1111/j.1469-8137.2012.04111.x.

34. Confraria, A., Elena, B. G. (2016). Using Arabidopsis protoplasts to study cellular responses to environmental stress. Methods in Molecular Biology, 1398, 247-269.

35. Liu, Y. S., Beyer, A., Aebersold, R. (2016). On the dependency of cellular protein levels on mRNA abundance. Cell, 165(3), 535-550. DOI 10.1016/j.cell.2016.03.014.

36. Yuji, S., Takeaki, M., Ryuichi, Y., Tadahiko, M., Amane, M. (2009). Rubisco content and photosynthesis of leaves at different positions in transgenic rice with an overexpression of RBCS. Plant, Cell \& Environment, 32(4), 417-427. DOI 10.1111/j.1365-3040.2009.01937.x. 